\title{
Hold Relax dan Passive Stretching Efektif Dalam Meningkatkan Kemampuan Fungsional Pada Pasien Post-Gips Fracture Tibial Plateau Dextra
}

\author{
Nizatul Mumtazah'), Faizah Abdullah Djawas ${ }^{2)}$ \\ Program Studi Fisioterapi Program Pendidikan Vokasi Universitas Indonesia \\ Kota Depok, Jawa Barat, Indonesia \\ Telepon : (021) 29027481 \\ Email: nizatulmumtazah@gmail.com
}

\begin{abstract}
Background: Tibial plateau fracture is one type of fracture that usually occur in legs. Tibial Plateau fracture usually occur because of high energy trauma that produced by the force of varus and valgus and also because of axial loading or because of the pedestrian that crashed by the car with high energy which can also called as fracture bumber. The purpose of this case study is to examine the effectiveness of hold relax and passive stretching in tibial plateau fracture. Method: case study, providing physiotherapy interventions for a 44yearold woman with a diagnosis of a tibial plateau post-cast fracture.Hold-relax stretching is a technique in which shortened antagonistic muscle groups are isometrically contracted against the optimal resistance given by the physiotherapist.Passive stretching is a method for extending the contractile or non-contractile components of the musculotendinoeus unit where force is exerted externally and given manually.Hold relax and passive stretching are given for 2 weeks with 5 evaluations. ROM assessment was measured by a goniometer and spasm by palpation.Result: There is an increase in LGSknee flexion $90^{\circ}$ to $110^{\circ}$ and decrease in spasm which associated with an improvement LEFS score from 17 to 44,indicates that there is an increase in the functional ability of lower extremity.Conclusion:This study shows that the method of therapeutic exercise with hold relax and passive stretching can improve functional ability in tibial plateau fracture which is measured using LEFS parameters.
\end{abstract}

\section{Keywords: Fracture tibial plateau, hold relax, passive stretching, LEFS}

\section{ABSTRAK}

Latar Belakang: Fraktur pada tibial plateau merupakan salah satu jenis fraktur pada kaki yang sering terjadi. Fraktur Tibial Plateu biasanya terjadi karena trauma dengan energi tinggi, biasanya dihasilkan oleh kekuatan varus atau valgus ditambah dengan pembebanan aksial atau juga pejalan kaki yang ditabrak mobil dengan energi tinggi atau bisa disebut dengan fracture bumper. Tujuan dari studi kasus ini adalah untuk mengetahui efektivitas dari dua intervensi yaitu hold relax dan passive stretching pada kasus fracture tibial plateau. Metode: Studi kasus tunggal, dengan memberikan intervensi fisioterapi pada seorang wanita 44 tahun dengan diagnosa post-gipsfracture tibial plateau. Hold-relax stretching merupakan suatu tehnik dimana group otot antagonis yang memendek dikontraksikan secara isometrik dengan melawan tahanan optimal yang diberikan fisioterapis. Passive stretching adalah metode untuk memperpanjang komponen kontraktil atau nonkontraktil dari unit musculotendinoeus dimana gaya yang diberikan dari luar dan diberikan secara manual. Hold relax dan passive stretching diberikan selama 2 minggu dengan 4 kali evaluasi. Penilaian ROM diukur dengan goniometer dan spasme dengan palpasi. Hasil: Terdapat peningkatan LGS lutut gerak fleksi $90^{\circ}$ menjadi $110^{\circ}$ serta penurunan spasme dikaitkan dengan skor LEFS dari nilai 17 menjadi 44, yang menunjukkan bahwa terdapat peningkatan kemampuan fungsional lower extremity pasien. Kesimpulan: Studi ini menunjukkan bahwa metode terapi latihan dengan hold relax dan passive stretching dapat meningkatkan kemampuan fungsional pada fracture tibial plateau yang diukur menggunakan parameter LEFS.

Kata Kunci: Fracture tibial plateau, hold relax, passive stretching, LEFS 


\section{PENDAHULUAN}

Fraktur merupakan hilangnya kontinuitas tulang, baik yang bersifat total maupun sebagian, biasanya disebabkan oleh trauma. Terjadinya suatu fraktur lengkap atau tidak lengkap ditentukan oleh kekuatan, sudut, tenaga, keadaan tulang serta jaringan lunak di sekitar tulang. ${ }^{1}$ Fraktur Tibial Plateu biasanya terjadi karena trauma dengan energi tinggi, biasanya dihasilkan oleh kekuatan varus atau valgus ditambah dengan pembebanan aksial. ${ }^{2}$

World Health of Organisation (WHO) mencatat pada tahun 2011-2012 terdapat 5,6 juta orang meninggal dunia dan 1,3 juta orang menderita patah tulang atau fraktur akibat kecelakaan lalu lintas. ${ }^{3}$ Menurut data kepolisian RI tahun 2018 sejak bulan April hingga Juni 2018 tercatat telah terjadi 26.755 kasus kecelakaan lalu lintas di seluruh Indonesia. ${ }^{4}$ Menurut Depkes RI 2011, dari sekian banyak kasus fraktur di Indonesia, dan dengan jenis fraktur yang paling banyak terjadi yaitu fraktur pada bagian ektremitas atas sebesar $32,7 \%$ dan ekstremitas bawah sebesar $46,2 \% .^{5}$

Penanganan medis untuk fraktur itu sendiri terbagi menjadi dua yaitu secara operatif dan non-operatif. Penanganan dengan metode operatif meliputi operasi open reduction external fixation (OREF) dan open reduction internal fixation (ORIF).

Fraktur dengan penanganan non-operatif yaitu dilakukan tanpa pembedahan dengan cara memakai cast atau gips. ${ }^{6}$ Imobilisasi anggota tubuh yang terluka telah dilakukan selama ribuan tahun. Sebelum bahan casting kontemporermenjadi banyak digunakan, orang menggunakan berbagai bahan untuk membentuk gips yang kaku. Selama berabad-abad imobilisasi telah berevolusi dari menggunakan pelat kayu sederhana dan kain plester paris, serat dan gips lunak. ${ }^{7}$ Dengan penanganan tersebut akan mengakibatkan berbagai masalah seperti gangguan gerak dan fungsi, adanya oedema, dan nyeri yang hebat.

Pada kondisi pasien dengan kasus PostGips Fracture Tibial Plateau Dextra fisioterapi dapat memanfaatkan terapi latihan berupa hold-relax dan passive streching. Hold-relax adalah suatu teknik dimana group otot antagonis yang memendek dikontraksikan secara isometrik dengan melawan tahanan optimal yang diberikan fisioterapis. ${ }^{8}$ Passive Stretching adalah metode untuk memperpanjang komponen kontraktil atau nonkontraktil dari unit musculotendinoeus dimana gaya yang diberikan dari luar dan diberikan secara manual. ${ }^{9}$

\section{TINJAUAN PUSTAKA}

\subsection{Fracture Tibial Plateau}

Fraktur pada tibial plateau kebanyakan terjadi pada orang dewasa.Fraktur Tibial Plateu biasanya terjadi karena trauma dengan energi tinggi, biasanya dihasilkan oleh kekuatan varus atau valgus ditambah dengan pembebanan aksial. Pemuatan aksial yang lebih besar mengarah pada peningkatan yang memunkinkan melibatkan bikondilar. Terjadi terutama setelah kecelakaan kendaraan bermotor, jatuh dari ketinggian atau pejalan kaki ditabrak mobil, sehingga dikenal juga dengan istilah fracture bumper. ${ }^{2}$

Fraktur tibial plateau terjadi pada $1 \%$ kasus dari semua fraktur dan $8 \%$ kasus terjadi pada pasien lanjut usia. Dengan $72 \%$ kejadian pada pasien berusia lebih dari 55 tahun. Fraktur yang terjadi pada pasien usia lanjut merupakan hasil dari trauma dengan energi rendah. Fraktur pada medial plateau terjadi pada $23 \%$ kasus fraktur plateau sedangkan fraktur lateral plateau terjadi pada $70 \%$ kasus, dan kombinasi antara keduanya terjadi pada $31 \%$ kasus. Pada wanita lebih banyak terjadi fraktur medial atau bicondylar (31\%) dan faktur kompresi posterior (61\%). Sedangkan pada pasien yang lebih muda paling banyak terjadi di kondilus lateral. ${ }^{2}$

Fracture tibial plateau diklasifikasikan berdasarkan sistem Klasifikasi Schatzker, yaitu: a. Schatzker I : adalah fraktur split atau wedge dari aspek lateral plateau biasanya adalah hasil dari valgus dan paksaan axial, b. Schatzker II adalah fraktur lateral wedge atau 
fraktur split yang dihubungkan dengan tekanan, c. Schatzker III adalah fraktur kompresi murni dari plateau lateral, sebagai hasil dari tekanan axial, d. Schatzker IV adalah fraktur yang melibatkan plateau medial sebagai hasil dari antara varus atau kompresi split, e. Schatzker V adalah tipe fraktur yang melibatkan elemen split pada kedua kondilus medial dan lateral dan mungkin melibatkan kompresi articular medial atau lateral, f. Schatzker VI adalah fraktur yang kompleks, bikondilar dimana komponen-komponen condylar terpisah dari diafisis, fragmen fraktur impaksi dan depresi adalah cirinya. ${ }^{10}$

BeradasarkanInternational Classification of Functioning, Disability and Health (ICF), diagnosis fisioterapi pada kasus post-gips fracture tibial plateau adalah Impairment; keterbatasan ROM, kelemahan otot, spasme otot, adanya nyeri gerak dan nyeri tekan, oedema pada daerah sekitar fraktur. Functional Limitation berupa pasien tidak mampu melakukan aktifitas fungsional seperti kesulitan dalam toileting jongkok, naik turun tangga, melompat, dan Participation Restriction berupa masalah yang dialami seseorang dalam situasi aktivitas sosial seperti tidak dapat bekerja kembali, tidak dapat mengikuti acara kumpul bersama temantemannya.

\subsection{Metode dan Teknik Intervensi}

Hold-relax stretching merupakan suatu teknik dimana group otot antagonis yang memendek dikontraksikan secara isometrik dengan melawan tahanan optimal yang diberikan fisioterapis. Kemudian diikuti dengan rileksasi, otot agonis dikontraksikan secara isotonik untuk mengulur otot antagonis yang mengalamispasme atau memendek. Pemberian intervensi ini bertujuan sebagai rileksasi dan penguluran otot, meningkatkan lingkup gerak sendi, dan mengurangi nyeri. ${ }^{9,11}$

Passive Stretching adalah metode untuk memperpanjang komponen kontraktil atau nonkontraktil dari unit musculotendinoeus dimana gaya yang diberikan dari luar dan diberikan secara manualPada teknik ini merupakan teknik yang dilakukan oleh terapis secara manual mengontrol lokasi stabilisasi serta arah, kecepatan, intensitas dan lamanya durasi peregangan. ${ }^{9}$

\subsection{Pemeriksaan dan Pengukuran}

Pengukuran Lingkup Gerak Sendi (LGS) dilakukan dengan goniometer pada titik fulkrum regio yang akan digerakan. dilakukan oleh sendi pada salah satu dari 3 bidang tubuh (frontal, sagital, transversal). Dimana menggunakan sistem dengan posisi awal semua gerakan dianggap $0^{\circ}$ dan kemudian bergerak hingga $180^{\circ} .{ }^{12}$

Spasme adalah pemeriksaan dilakukan untuk mengetahui ada tidaknya ketegangan, berkaitan dengan intervensi yang akan dilakukan.

The Lower Extremity Functional Scale (LEFS) adalahsebuah parameter yang dapat digunakan untuk mengevaluasi pasien dengan gangguan muskuloskeletal atau gangguan ekstremitas bawah. ${ }^{13}$ Parameter ini berisi 21 pertanyaan tentang kemampuan seseorang untuk melakukan aktivitas sehari-hari. Skala penilaian 0-80. Nilai maksimum yang mungkin didapat adalah 80 poin menunjukkan fungsi yang sangat tinggi. Skor minim-um adalah 0 poin yang menunjukkan fungsi yang sangat rendah, semua 20 pertanyaan dinilai dengan skor maksimum 4 untuk setiap pertanyaan. $(0=$ Tidak mampu, $1=$ Sangat kesulitan, 2=Cukup kesulitan, 3= Kesulitan ringan, 4= Tidak ada kesulitan), kolom pada skala dijumlahkan untuk mendapatkan skor akhir, pasien diberikan 20 pertanyaan di atas kertas dan diinstruksikan untuk menunjukkan tingkat kesulitan saat ini setiap aktivitas.

\section{Metode Penelitian}

\subsection{Rancangan Penelitian}

Merupakan studi kasus tunggal dengan desain penelitian pre dan post test yaitu membandingkan antara skor sebelum dan sesudah intervensi hold relax dan passive stretching exercise. 


\subsection{Subjek}

Seorang wanita usia 44 tahun dengan diagnosis medis post-gips fracture tibial plateau dextra, memiliki keluhan utama tidak bias menekuk lutut kanannya. Riwayat penyakit yaitu, padatanggal 6 Oktober 2019 pasien mengalami kecelakaan saat sedang memasukkan barang dibagasi mobilnya, tibatiba ada mobil dari belakang yang menghantam dirinya dan mengakibatkan pasien terhimpit 2 mobil kurang lebih selama 25 menit. Pasien lalu di bawa ke RSUP Fatmawati untuk penangnan darurat dan menjalani rawat inap. Pada esok harinya tanggal 7 Oktober 2019, dokter mengatakan bahwa terdapat fraktur di daerah bawah lutut sebelah kanan pasien. Kemudian, pada tanggal 15 Oktober 2019 dilakukan pemasangan gips pasien mulai melakukan latihan berjalan dengan menggunakan tongkat dengan kaki sebelah kanannya belum menapak lantai. Setelah satu bulan, pada tanggal 15 November 2019 pasien melepas gips. Namun, setelah beberapa minggu melepas gips pasien tidak dapat menekuk lutut kanannya, lalu pasien dirujuk oleh dokter ortopedi ke fisioterapi. Pasien melakukan fisioterapi pertama pada tanggal 21 Desember 2019.

Subjek memilik kesadaran composmentis, pasien kooperatif, dan cara datang pasien menggunakan crutches. Setelah dilakukan pemeriksaan umum, vital sign pasien berkesan baik, tapi IMT pasien terkesan gemuk.

Kesulitan aktivitas yang dirasakan pasien saat ini adalah toileting jongkok, naik turun tangga, dan melompat. Pada pemeriksaan ditemukan adanya keterbatasan ROM flexi knee dextra, spasme otot dan diukur dengan parameter LEFS.

\subsection{Tempat dan Waktu}

Penelitian dilakukan di poli fisioterapi RSUP Fatmawati dan penelitian dulakukan mulai 14 Februari sampai 27 Februari 2020.

\subsection{Penatalaksanaan Intervensi}

Pemberian terapi latihan dengan metodehold relax dan passive stetching. Dosis latihan untuk Hold Relax dengan frekuensi 2x seminggu, dengan hold 8 detik, rest 30 detik dan dilakukan 10x repetisi. ${ }^{14,15}$ Untuk Passive Stretching diberikan dosis dengan frekuensi $2 \mathrm{x}$ seminggu, durasi 30 menit dan dilakukan 10x repetisi atau toleransi pasien. ${ }^{16}$

\section{HASIL DAN PEMBAHASAN}

\subsection{Hasil}

Hasil dari 5 kali evaluasi pemberian selama 2 minggu pada subjek penelitian didapatkan hasil berupa :

\section{Skor ROM}

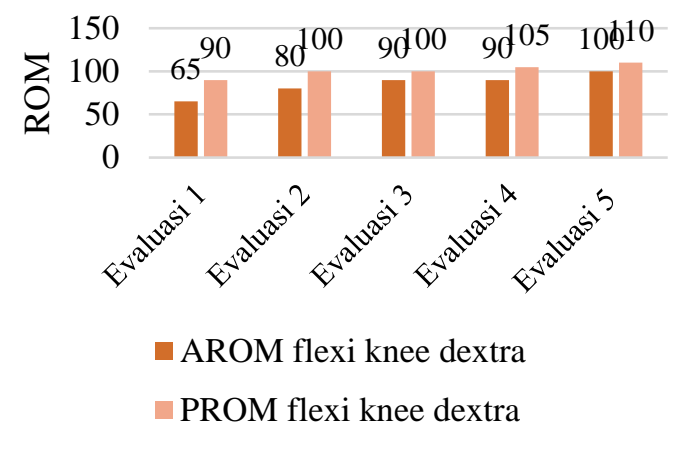

Gambar Grafik 1 Evaluasi ROM

Berdasarkan dari grafik diatas didapatkan hasil yang berupa peningkatan ROM pada lutut kanan yang diukur dengan menggunakan goniometer, dan didapatkan hasil untuk AROM flexi knee dextra dari $65^{\circ}$ pada evaluasi 1 menjadi $100^{\circ}$ pada evaluasi ke 5, sedangkan untuk PROM flexi knee dextra dari $90^{\circ}$ pada evaluasi 1 menjadi $110^{\circ}$ pada evaluasi ke 5 . 


\begin{tabular}{llllll}
\hline Spasme & Eva & Eval & Eva & Eva & Eva \\
Otot & luas & uasi & luas & luas & luas \\
& i 1 & 2 & i 3 & i 4 & i 5 \\
& $(14-$ & $(17-$ & $(20-$ & $(25-$ & $(27-$ \\
& $02-$ & $02-$ & $02-$ & $02-$ & $02-$ \\
& 202 & 2020 & 202 & 202 & 202 \\
& $0)$ & ) & $0)$ & $0)$ & $0)$ \\
\hline $\begin{array}{l}\text { Spasme } \\
\text { Hamstr }\end{array}$ & Ada & Ada & Ada & Ber & Ber \\
ing & & & & kura & kura \\
Spasme & Ada & Ada & Ada & Ber & Ber \\
Quadri & & & & kura & kura \\
ceps & & & & ng & ng \\
Spasme & Ada & Ada & Ada & Bek & Ber \\
Gastro & & & & uran & kura \\
cnemiu & & & & g & ng \\
s & & & & & \\
\hline
\end{tabular}

Tabel 2 Evaluasi Spasme

Berdasarkan dari tabel diatas, terdapat penurunan pada spasme otot. Yang terlihat pada evaluasi 1 terdapat spasme di m.hamstring, m.quadriceps, m.gastroc dan spasme berkurang pada evaluasi ke 5 .

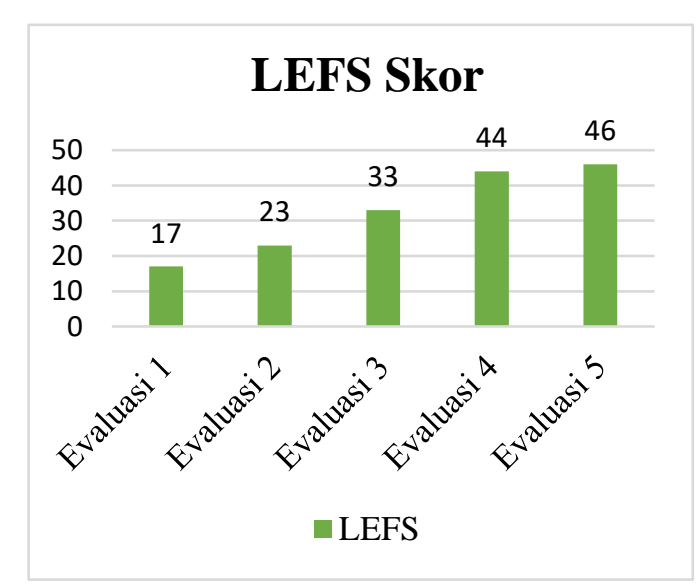

Grafik 3 Evaluasi LEFS

Pada grafik diatas menjelaskan hasil yang didapat pada evaluasi LEFS dengan skor 17, evaluasi 2 LEFS dengan skor 23, evaluasi 3 LEFS dengan skor 33, evaluasi 4 dengan skor 44 hingga menjadi nilai 46 pada evaluasi ke 5. Dalam hal ini semakin besar skor yang diperoleh oleh pasien maka kondisi pasien semakin membaik.

\subsection{Pembahasan}

\section{Hold Relax Terhadap Peningkatan Lingkup Gerak Sendi dan Spasme}

Pemberian holdrelax stretching bertujuan untuk meningkatkan ROM, mengurangi nyeri, dan spasme, hal ini didukung oleh studi yang dikemukakan oleh Jason Wicke et al bahwa hold relax efektif dalam berbagai kondisi, seperti dalam meningkatkan panjang otot yang disebabkan karena pemendekan, meningkatkan vasodilatasi darah, dan meningkatkan lingkup gerak sendi. ${ }^{17}$ Dan karena adanya penurunan ketegangan otot berkaitan dengan peningkatan panjang otot. Sehingga dengan demikian dapat dikatakan bahwa hold relax juga dapat mengurangi spasme dan nyeri akibat ketegangan pada otot. ${ }^{8}$

Teknik hold relax itu sendiri merujuk pada aktifitas golgi tendon dan muscle spindel. Muscle spindel bertanggung jawab menerima dan memberikan informasi perubahan panjang dan kecepatan perubahan yang terjadi di otot atau yang biasa yang disebut sebagai stretch receptor. Golgi tendon berperan dalam mekanisme proteksi melalui autogenic inhibition, golgi tendon ini akan merileksasi otot setelah 6 detik. Kontraksi isometrik yang dilakukan pada otot yang mengalami ketegangan berlebih akan memfasilitasi terjadinya autogenic inhibition, suatu refleks untuk relaksasi yang muncul pada otot saatgolgi tendonnya terstimulasi. ${ }^{11,18}$

Intervensi hold relax dilakukan 2 kali seminggu dengan waktu kontraksi 8 detik dan repetisi 10 kali. Intervensi ini diberikan berdasarkan studi yang dilakukan Hashim ahmed, et al 
membuktikan bahwa hold relax selama tujuh detik kontraksi isometrik dan kemudian rileks selama lima detik efektif dalam meningkatkan fleksibilitas otot hamstring. ${ }^{19} \mathrm{Hal}$ ini juga didukung oleh penelitian yang dilakukan Cho Sun Ik et al, dengan merekomendasikan hold relax dengan kontraksi isometrik untuk agonis selama tujuh hingga delapan detik, lalu rileks selama dua hingga lima detik, dan kontraksi untuk agonis tujuh hingga delapan detik dan kemudian ulangi empat hingga enam kali yang terbukti efektif untuk meningkatkan lingkup gerak sendi. ${ }^{14}$ Sharman et al mengemukakan bahwa agar mendapatkan hasil yang efektif latihan hold relax harus dilakukan 1-2 kali per minggu untuk dapat meningkatkan lingkup gerak sendi. ${ }^{15}$ Rowland et al menambahkan kontraksi selama 10 detik efektif untuk meningkatkan fleksibilitas otot. ${ }^{20}$

\section{Passive Stretching Terhadap Peningkatan ROM}

Penulis menggunakan teknik passive stretching yang dilakukan 2 kali seminggu dengan waktu kontraksi 30 detik dan 8 kali repetisi. Intervensi ini ini diberikan berdasarkan studi yang dilakukan McHugh et al passive stretching memegang mebentang selama 20 hingga 30 detik adalah standar yang baik karena sebagian besar relaksasi stres dalam passive stretching terjadi dalam 20 detik pertama. Pasien bisa merasakan ini mengurangi ketegangan otot ketika mereka tahan regangan statis. ${ }^{16}$ Borms et al membandingkan efek peregangan dari 10, 20 dan 30 detik dengan peregangan statis, yang berlangsung selama 10 minggu dan terdiri dari dua sesi seminggu, dan membuktiktan bahwa passive stretching dapat meningkatkan ROM. ${ }^{21}$
Hal ini dikarenakan passive stretching adalah metode untuk memperpanjang komponen kontraktil atau non kontraktil dari unit musculotendinoeus dengan gaya yang diberikan dari luar dan diberikan secara manual. ${ }^{9}$ Untuk mencapai otot passive stretching adalah dijalarkan melalui jaringan ikat (perimysium dan endomisium) keserat otot. Jaringan lunak dielongasi tepat melewati titik tahanan jaringan kemudian dipertahankan dalam posisi memanjang dengan gaya regangan terus- menerus selama beberapa waktu untuk mengarah ke peningkatan panjang sarkomer alat kontraktil harus dihubungkan dengan nonkontraktil. Untuk menjelaskan apakah otot meregang, akhirnya mengarah ke serat otot yang lebih panjang dengan lebih banyak sarkomer seri (myofibrillogenesis), pengindraan sinyal, transduksi sinyal dan transkip gen selanjutnya harus terjadi, sehingga terjadi sarcomere yang dimana secara tidak langsung otot akan memanjang (distraction osteogenesis). ${ }^{22}$

Hal ini sejalan dengan hasil evaluasi yang didapat dalam penelitian pada pasien dalam studi kasus ini.

\section{LEFS Terhadap Kemampuan Functional Lower Exremity}

Bukti langsung penerapan hold relax dan passive stretching belum ditemui hingga saat ini, namun secara tidak langsung pemberian kedua intervensi tersebut berpengaruh pada kemampuan fungsional, melaluipeningkatanLGS. Dimana kemampuan fungsional pasien saat berjongkok, toileting serta naik turun tangga, melompat diperlukannya ROM yang normal dan semakin baik. 


\section{KESIMPULAN}

Metode terapi latihan hold relax dan passive stretching dinilai efektif dalam meningkatkan kemampuan fungsional pada pasien fraktur tibial plateau yang dinilai menggunakan parameter LEFS.

\section{REFERENSI}

1. Helmi ZN. Buku Ajar Gangguan Muskuloskeletal. 2011. p411-55 p.

2. Rozell JC, Vemulapalli KC, Gary JL, Donegan DJ. Tibial Plateau Fractures in Elderly Patients. 2016;7(3):126-34.

3. Enst M, Anab R, Tez D, Dan LU, Yilmaz S, Baran Z, et al. World Health Statics. Vol. 16, Acta Universitatis Agriculturae et Silviculturae Mendelianae Brunensis. 2015. 24-25 p.

4. Chief of Traffic Corps Indonesian National Police. Traffic Corps in Number 2013. 2014;1-41.

5. Riskesdas K. Hasil Utama Riset Kesehata Dasar (RISKESDAS). J Phys A Math Theor. 2018;44(8):1-200.

6. Apley AG. Apley's System of Orthopaedics and Fractures. 9th editio. 2010; 2010.

7. Limb I. Plaster of Paris - Short History of Casting and Injured Limb. 2017;44(0):291-6.

8. Phil P. Clinical Commentary Current Concepts In Muscle Stretching For Exercise And Rehabilitation. Int J Sport Phys Ther. 2012;7(1):109-19.

9. Carolyn Kisner dan Lynn Allen Colby. Therapeutic Exercise. Foundation. Phialpia: F.A. Davis Company; 2007.

10. Exhibit E. Schatzker Classifica- tion of Tibial Plateau Fractures: Use of CT and MR Imaging Improves Assessment 1. 2009;585-98.

11. Hindle KB, Whitcomb TJ, Briggs WO, Hong J. Proprioceptive Neuromuscular Facilitation ( PNF ): Its Mechanisms and Effects on Range of Motion and Muscular
Function by. 2012;31(March):105-13.

12. Reese NB. Joint Range of Motion and Muscle Length Testing- E-Book. Elsevier Health Sciences; 2016.

13. Mehta SP, Fulton A, Quach C, Thistle M TCE. Measurement properties of the lower extremity functional scale: a systematic review. :1-39.

14. Cho S, Lee D, Hong J, Yu J, Kim J. Effect of Hold and Relax Technique on Knee Joint Position Awareness in Normal Adults. 2015;8(August):1-5.

15. Sharman MJ, Cresswell AG, Riek S. Facilitation Stretching Mechanisms and Clinical Implications. 2006;36(11):92939.

16. Knudson D. The Biomechanics of Stretching. 1999;3-12.

17. Wicke Jason. A c s - p n f s s r m f. 2014;168-72.

18. Victoria GD, Carmen E, Alexandru S, Florin C, Daniel D. The PNF ( Proprioceptive Neuromuscular Facilitation) Stretching Technique. 2013;XIII(2):623-8.

19. Hashim A, Amir I et al. Effect of modified hold-relax stretching and static stretching on hamstring muscle flexibility. 2015;114.

20. Rowlands A V, Marginson VF, Lee J. Chronic Flexibility Gains: Effect of Isometric Contraction. Res Q Exerc Sport. 2013;(July):37-41.

21. Roberts JM, Wilson K. Evect of Stretching Duration on Active and Passive Range of Motion in The Lower Extremity. 1999;259-63.

22. Deyne PG De. Application of Passive Stretch and Its Implications for Muscle Fibers. 2018;81(2):819-27.

\section{Nama Penulis}

1. Nizatul Mumtazah, memperoleh Ahli Madya Fisioterapi pada tahun 2020 dari D-III di Program Pendidikan Vokasi Universitas Indonesia. 
2. Faizah Abdullah, memperoleh gelar Ahli Madya Fisioterapi pada tahun 2010 dari D-III Fisioterapi, Fakultas Kedokteran Universitas Indonesia. Kemudian pada tahun 2012 memperoleh gelar Sarjana Sain Terapan Fisioterapi dan Sarjana Fisioterapi dari Fakultas Fisioterapi Universitas Esa Unggul. Tahun 2017, mendapatkan gelar Megister Ilmu Biomedik, Fakultas Kedokteran Universitas Indonesia. Saat ini bekerja sebagai Dosen Tetap Program Studi Fisioterapi Program Pendidikan Vokasi Universitas Indonesia 